Review

\title{
Equol's Anti-Aging Effects Protect against Environmental Assaults by Increasing Skin Antioxidant Defense and ECM Proteins While Decreasing Oxidative Stress and Inflammation
}

\author{
Edwin D. Lephart
}

Department of Physiology and Developmental Biology and The Neuroscience Center, LSB 4005, College of Life Sciences, Brigham Young University, Provo, UT 84602, USA; Edwin_Lephart@byu.edu; Tel.: +1-801-319-8173

Received: 30 November 2017; Accepted: 22 January 2018; Published: 29 January 2018

\begin{abstract}
Environmental pollutants represent a major problem worldwide that cannot be passively avoided. It is known that skin sensitivities can result from environmental assaults, such as toxins and pollutants in air and water. Additionally, dermal assaults from wind and exposure to seasonal cold temperatures are known. All of these environmental assaults are associated with oxidative stress and the intracellular generation of reactive oxygen species (ROS), which damage DNA, lipids, proteins and mitochondrial function. Additionally, the influence of diet on dermal health and, especially, antioxidant defense in skin function are well established. In this regard, environmental pollution worldwide has generated a high demand for anti-pollution personal care products to protect the skin against the daily exposure of airborne toxins and various other assaults. Major cosmetic companies have anti-pollution personal care products but, in general, the products are formulated with commonly used active ingredients that have been retooled with market strategies to address current environmental pollution treatments. Equol is a new botanical active ingredient compound for skin applications. It has a polyphenolic chemical structure found in plant and food products, and is also classified as an isoflavonoid. Moreover, equol appears to address the need for an active ingredient in personal care products to protect against pollution assaults by increasing antioxidant defense, while inhibiting oxidative stress and inflammation. Separate sections covering equol's enhanced (a) delivery mechanism into human skin; (b) antioxidant effects via Nrf2 activation; (c) effects on extracellular matrix proteins like collagen and elastin and; (d) protection against oxidative stress and inflammation are presented.
\end{abstract}

Keywords: skin aging; pollution; equol; antioxidant; ECM proteins; oxidative stress; inflammation

\section{Introduction}

Human skin is the largest, and a complex, organ functioning as a physical barrier to protect the body from environmental assaults, such as pathogens, chemicals, physical agents, and solar ultraviolet radiation (UVR) throughout life [1,2]. The skin also provides essential physiological functions, including immune defense, thermoregulation, sensory input from mechanoreceptors, as well as endocrine and metabolic mechanisms to sustain optimal health [2]. Finally, and most importantly, the antioxidant defense capacity of the skin is greater compared to internal organs due to the protective structural and biological functioning of the dermal layers [1,2]. Skin aging can be classified by intrinsic (chronological) and extrinsic (photoaging) mechanisms [1,2]. This brief review focuses on extrinsic skin aging that examines environmental factors, such as pollution, which represent a major cause of concern worldwide. Pollution is associated with the generation of reactive oxygen species (ROS), which 
damage DNA, lipids, proteins, mitochondrial function, and increases inflammation [2]. In reference to antioxidants defense, it is well known that diet can influence dermal health [3]. Many major cosmetic companies have anti-pollution personal care products with topical and/or oral applications to address current environmental concerns. However, there is always a need to identify and develop new active ingredients for skin applications that would address environmental assaults. Equol, a novel botanical active ingredient compound appears to potentially protect against pollution assaults via a variety of mechanisms to increase antioxidant defense, while also decreasing oxidative stress and inflammation [2]. Separate sections on perceptions of skin sensitivity, environmental factors of pollution, sources of oxidative stress, diet and the influence of antioxidants, and equol's apparent protective effects against environmental assaults are presented.

\section{Perceptions of Sensitive Skin with Environmental Causes}

Environmental factors are strongly associated with sensitive skin [4]. For example, approximately ten years ago, Farage from Procter and Gamble reported that 50 to almost 70\% of women reported skin sensitivity worldwide [4]. A subsequent study by Farage et al. in 2013 confirmed several previous studies by demonstrating that women in every region of the United States, like women in other parts of the world, reported some degree of skin sensitivity at fairly high levels [5]. In this latter report, the authors concluded that it is increasingly recognized that psychosocial influences, as well as biological and environmental factors, contribute to skin sensitivity [5]. Neuropsychiatric factors in sensitive skin such as environmental conditions and psychological (stress) have been recently reviewed by Misery in 2017 [6]. In general, sensitive skin is a common disorder that can induce changes in the quality of life and has psychological consequences [6]. Moreover, the study by Farage in 2008 showed that stress was the factor most strongly associated with perceived sensitive skin especially on the face [4].

While "stress" in the Farage report, in 2008, was not well defined, the complex process of skin aging (and disease, in general) was determined by intrinsic, extrinsic, and infectious factors [4]. In this case, "stress" may be the real or perceived impact of various factors that in turn change a person's self-perception with a declination in feeling good about one's self, especially of how they look or are perceived by others. For example, whether a person goes through dermal trauma from war or accidental means compared to individuals experiencing intrinsic (chronological) skin aging, the impact on patients in regard to positive self-perception is paramount and comparable, especially if the events/changes occur in highly-visible body areas, such as the face, neck, hands, and arm regions $[7,8]$.

In regards to environmental factors exposure to sunlight, chemicals, pesticides, heavy metals, or other contaminants, plus various diseases, disorders, or trauma, along with unhealthy lifestyles, like tobacco smoking, alcohol consumption, and poor choice of diet, influence the generation of reactive oxygen species (ROS) [9]. If the generation of ROS overwhelms endogenous antioxidant protection within the body, this subsequently leads to oxidative stress or damage [9]. Thus, oxidative stress is a process caused by ROS, which are unstable molecules whereby they damage or "oxidize" cells in the body, similar to a sliced apple that turns brown when exposed to air is oxidized [9].

It is well established that all of these categories (intrinsic, extrinsic and infectious factors) can increase oxidative stress that in turn alter or damage DNA, cells, and tissues (see Figure 1) [9-12]. Additionally, it is well known that oxidative stress is a major source of skin aging, and the mechanisms by which it occurs have been reviewed $[2,13,14]$. Finally, since the skin is the first line of defense, there are several important antioxidant enzymes in human skin $[2,15,16]$. Antioxidants are known to block free radicals and /or ROS from stealing electrons from other atoms; notably, superoxide dismutase (SOD), catalase, and glutathione peroxidase are examples. Other molecules derived from our diet, such as vitamins A, C, and E, can also act as antioxidants which are found in high concentrations in the epidermis and dermis [2,15-17]. In other words, an antioxidant is any substance that inhibits damage due to oxygen (oxidation) that is caused by ROS. 


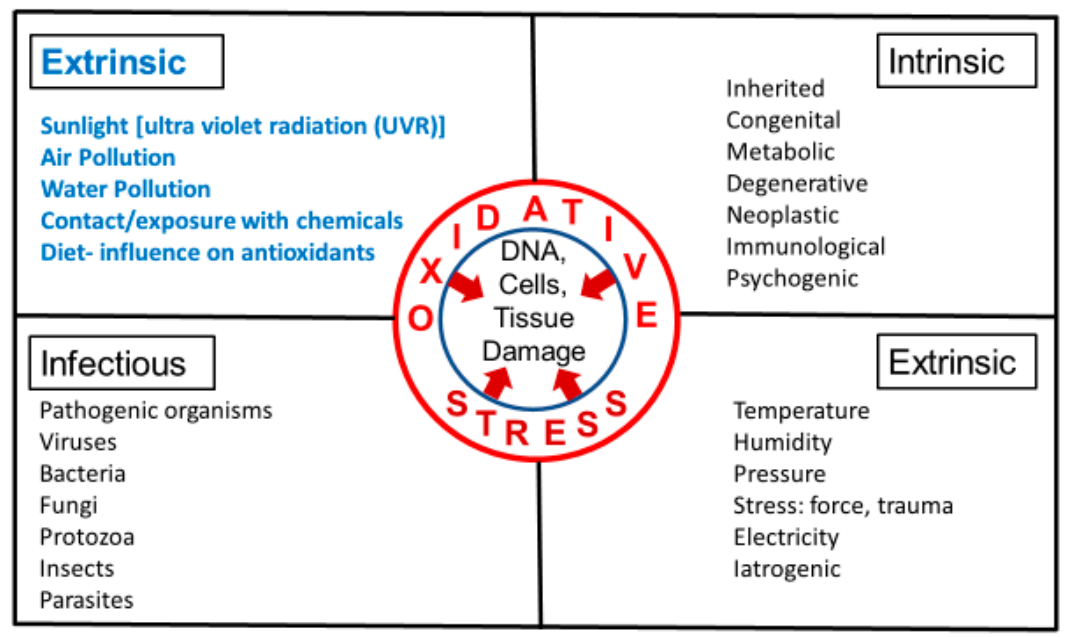

Figure 1. Intrinsic, extrinsic, and infectious factors that lead to oxidative stress and subsequent DNA, tissue and cell damage. The extrinsic factors listed in the upper left-hand corner are covered in this review. Sunlight, air/water pollution, and exposure to chemicals are known to increase oxidative stress, while dietary intake can influence antioxidant levels that are known to counteract oxidative stress and ROS.

\section{Intrinsic and Extrinsic Sources of Oxidative Stress}

Human skin aging can be classified mainly by intrinsic and extrinsic mechanisms (along with infectious or disease factors). Intrinsic or chronological aging is the unavoidable occurrence that includes several influences like genetics, metabolism, and the passage of time, where repair functions become slow or defective $[2,13,18-21]$. For example, in intrinsic aging, there is ROS production via normal oxidative metabolism within cells that is inevitable, but contributes in a modest way to skin aging compared to extrinsic aging $[2,18,19]$. Extrinsic aging comes from external sources that increase oxidative stress, which include sunlight, especially ultraviolet radiation (UVR), temperature conditions, like cold weather, and air/water pollution. In this regard, the dietary intake of food sources containing antioxidants are known to decrease ROS [2,7,9,22]. Both intrinsic and extrinsic factors contribute to the generation of ROS-mediated oxidative stress that can impair and damage skin structure and function $[2,22]$. Presumably, extrinsic factors associated with sunlight represent a major impact on skin aging $[2,22]$.

\section{Environmental Factors that Influence Generation or Inhibition of ROS}

\subsection{Sunlight Photoaging and the Generation of ROS}

Extrinsic aging can be avoided to some extent, since it is due to environmental exposure, primarily to solar UV radiation (UVR) or ultraviolet (UV) light from artificial tanning sources, both of which are commonly referred to as photoaging. Photoaging is the long-term UVR or UV exposure and the resulting solar damage superimposed on intrinsically aged skin $[2,13]$. It is thought that up to $80-90 \%$ of skin aging is due to the deleterious effects of sunlight or photoaging $[2,13]$.

There are different types of solar radiation: UVR contributes approximately $5 \%$, visible light about $42 \%$, and infrared light around $53 \%$ of the content of sunlight $[13,23]$. The UVR classification accounting for approximately $5 \%$ of the total content of sunlight can be subdivided into three categories by wavelength; UVA (320-400 nm), UVB (280-320 nm,) and UVC (100-280 nm) [13] (see Figure 2). UVC rays are blocked by the ozone layer and do not reach the surface of the Earth [23]. UVA and UVB rays make up $95-98 \%$ and $2-5 \%$, respectively, of the UV radiation reaching human skin [23]. However, several factors influence the amount of UVB exposure, such as solar zenith angle, latitude, stratospheric ozone levels, pollution, weather-cloud cover, and altitude [23]. 
UVB (280-320 nm), while representing only 2-5\% of the sun's emissions, penetrates into epidermal cells, can damage DNA and activate a cascade of events leading to the generation of ROS and increased photo-aging $[2,13,23,24]$. Conversely, UVA $(320-400 \mathrm{~nm})$ at a higher wavelength range represents 95-98\% of the total UV radiation reaching the Earth's surface can damage the epidermis and penetrates deeper into the dermis to degrade collagen and elastin fibers via oxidative stress mechanisms that in turn activate matrix metalloproteinases (MMPs) and damage mitochondrial structure/function that leads to extrinsic skin photoaging $[2,13,14]$. Thus, most UV-induced oxidative stress is generated by UVA, which is more cytotoxic to human skin compared to UVB; whereas UVB are mostly mutagenic, both are known to stimulate the generation of ROS, [2,13,14,25] (see Figure 2).

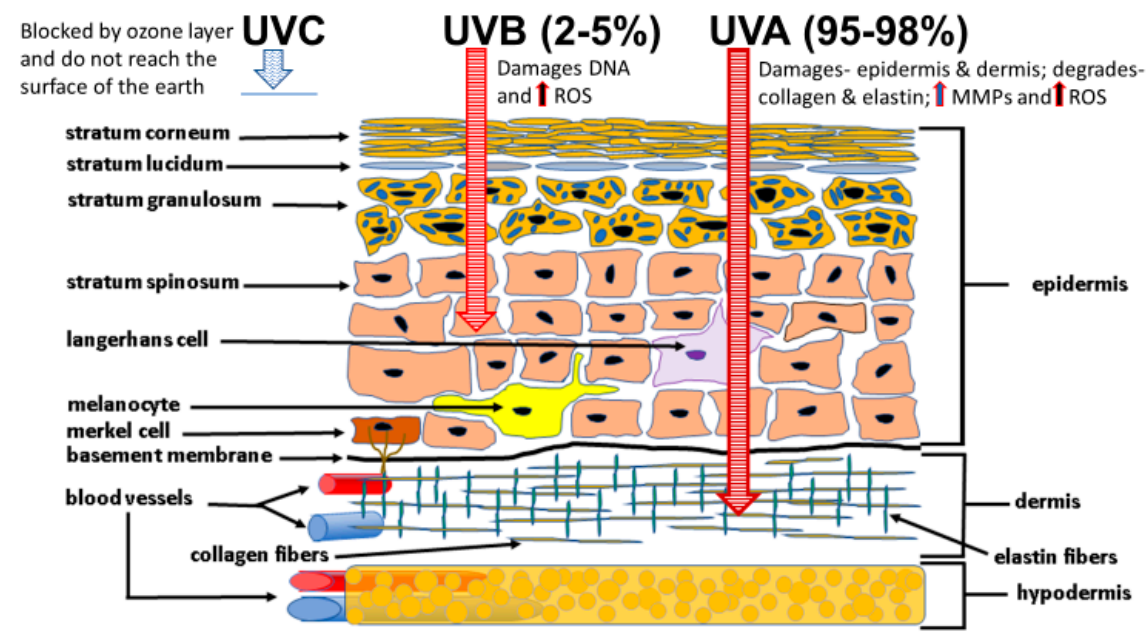

Figure 2. Human skin layers as influenced by ultraviolet radiation (UVR). The UVR classification accounts for approximately $5 \%$ of the total content of sunlight can be subdivided into three categories by wavelength; UVA (320-400 nm), UVB (280-320 nm), and UVC (100-280 nm) [10]. UVB rays account for approximately $2-5 \%$ of UVR and is known to penetrate the epidermis, damage DNA and increase oxidative stress and ROS [2,13]. UVA rays account for approximately 95-98\% of UVR and penetrates deeper into the epidermis and dermis, is known to degrade collagen and elastin, increase matrix metalloproteinases (MMPs) and increase oxidative stress and ROS [2,13,23-25]. This cartoon displays the epidermis, dermis, and hypodermis, along with the cellular components and extra cellular matrix elements. Redrawn, in part, with permission (see E.D. Lephart, J. Cosmet. Dermatol., 2018, in press).

\subsection{Cold Weather and the Generation of ROS}

Health problems associated with cold weather include skin disorders and the effects of cold on skin has been reviewed by Lemuskallio et al., in 2002, and more recently by Makinen and Hassi, in 2009 [26,27]. These are especially true for those who work in cold environments or where being outside in cold temperatures with lengthy exposures can cause dry skin conditions or aggravate common dermatoses, such as atopic dermatitis and psoriasis [27]. A recent study by Briggs et al. in 2017 examined the rate of cooling of volunteer's faces in cold, windy outdoor conditions $\left(-14\right.$ to $\left.1^{\circ} \mathrm{C}\right)$ and quantified the amount of time that people were willing to spend outside before they were too cold and wanted to go indoors [28]. Additionally, thermal infrared imaging of each subject's face was quantified in this study. While the endpoints of thermal imaging at which people wanted to quit displayed a wide variance in the data, in general, it only took a few minutes before their faces were so cold that they wanted to go indoors. The human subjects exposed to low temperatures and high wind conditions displayed the quickest request interval to go indoors at around 4-5 min, whereas, low temperatures and low wind condition subject's requests to go indoors occurred around 8-10 min. Thus, windy, cold conditions represent an environmental factor, where facial cooling usually occurs within minutes, contributing to skin sensitivity [22,28]. 
Notably, the investigation by Farage, in 2008, reported that of all the environmental factors, cold weather was perceived by the highest percentage of subjects overall (81\%) as causing skin irritation [4]. While not well studied, cold exposure in humans is known to increase oxidative stress $[29,30]$. For example, being exposed to, or performing physical tasks in, cold conditions increased free radical production as seen by the elevation of reactive oxygen metabolites and the concomitant decrease of plasma antioxidants in human subjects $[29,30]$. Thus, cold weather appears to be a major concern of potential skin irritation, especially in women [4].

\subsection{Air and Water Pollution and the Generation of ROS}

Environmental pollution is increasing, especially in industrialized countries, and represents a worldwide problem that cannot be passively avoided [31]. Less research has been performed to date on environmental pollutants and human skin aging. However, it is well recognized that facial wrinkling is one of the most notable signs of skin aging [32]. Additionally, tobacco smoking is known to damage the skin and advance the aging process [32,33]. In this regard, some researchers suggest that environmental pollutants advance the aging process more than UVA and UVB damage. Others believe that pollutants can cause hyperpigmentation, inflammation, breakdown collagen, and elastin, resulting in rough and damaged skin, while many dermatologists currently believe UV rays are still the top priority in aging prevention [2,34].

The adverse effects of air pollution on human health have been studied in a variety of ways via epidemiological investigations, where a clear association between cardiovascular morbidity, decreased lung function, increased hospital admissions, mortality, and airborne particulate pollutants have been reported since the early 1990s [35,36]. Additionally, there is a strong body of evidence that indicates exposure to air pollution is mediated by oxidative stress in its damaging effects on many physiological functions $[35,37,38]$.

In reference to human skin aging, journal reports have shown that airborne pollutant exposure is correlated with extrinsic skin aging in adults and children [22,31,39]. However, air pollution represents either indoor or outdoor environmental exposure to any chemical, physical, or biological agent. The United States Environmental Protection Agency (EPA) has classified pollutants into six categories arising from metal/industrial plants (lead); particulate matter (PM) (both fine at 2.5 microns or 10 microns) or gases $\left(\mathrm{O}_{3}, \mathrm{CO}_{2}, \mathrm{CO}, \mathrm{SO}_{2}, \mathrm{NO}_{2}\right)$ from soot, exhaust or industrial sources; nitrogen oxide from car exhaust; sulfur oxide from industrial plants; or ozone (at ground level), all of which are known to generate ROS [3,40,41]. The first published reports on air pollution and skin aging appeared in the Journal of Investigative Dermatology in 2010 [42,43]. Both reports suggested that air pollution exposure was significantly correlated with extrinsic skin aging, particularly to pigment spots on the face and hands and, to a lesser extent, for wrinkles [42,43].

Subsequent publications on air pollution and skin aging from 2011 through 2014 demonstrated that: (a) airborne polychlorinated biphenyls (PBCs) reduced telomerase activity and shorten telomere length in human skin (HaCat) keratinocytes [44]; (b) free radicals and organic nanoparticles reduced human keratinocyte viability by apoptosis [43,45,46]; (c) eczema increased with exposure to PM of 10 microns or less in office indoor environments [47] and; (d) atopic dermatitis and other skin sensitivities or aging endpoints increased with air pollutants that are known to induce increased levels of ROS [48-50].

From 2015 to the present (2017) the number of published reports on air pollution and skin increased substantially and covered topics such as: (a) indoor air pollution from cooking accelerated skin aging in Chinese women, and atopic dermatitis increased from other indoor pollutants, such as polyvinyl chloride (PVCs) from wallpaper [51,52]; (b) decreased skin barrier function and increased facial hyperpigmentation (lentigines) from ambient PMs that are known to increase inflammatory skin diseases, ROS and matrix metalloproteinases (MMPs) that degrade collagen [53-57]; and (c) fine airborne PM activated the aryl hydrocarbon receptor (AHR) that resulted in detrimental effects on human keratinocytes [58,59]. Finally, in brief, two recent reviews have summarized the recognized 
negative impact of ambient air pollution on skin health, which suggested four general mechanisms by which this occurs: (1) generation of ROS; (2) induction of the inflammatory cascade and subsequent impairment of the skin barrier; (3) activation of the AHR which stimulates the expression skin aging genes such as MMPs that degrade collagen; and (4) alterations to the skin microflora [60,61].

Water pollution, to date, has not been examined in reference to skin health. Although, investigations that have quantified molecular biomarkers in aquatic organisms due to their sensitivity to oxidative stress demonstrated that ROS are present in environmental pollutants in water from field studies $[62,63]$.

\subsection{Diet and the Influence of Antioxidants that Inhibit ROS}

Dermatologist are well aware that skin disorders can result from poor nutrition, such as scurvy (vitamin C deficiency), atopic dermatitis, which is associated with essential fatty acid deficiency, and people who do not eat well do not look well; meaning eating better results in "better" looking skin $[3,17,64]$. Additionally, beginning in the 1990s, food lost its exclusive nutritional role and transformed into a prevention tool to preserve health from chronic, aging, and degenerative diseases that could increase wellness [65]. Following this prospect, the cosmetic industry found a novel opportunity to support traditional topical treatments with oral supplementation to enhance skin health [65]. Thus, what scientific information is available about diet, supplementation, and the benefits to skin health?

Recall that exposure to solar UVR, chemical agents, and other environmental pollutants are known to increase free radical or ROS formation along with the inescapable generation of ROS by normal metabolic cellular oxidation associated with mitochondrial function [2,21]. Hence, a healthy life free of disease becomes a matter of balance; biological systems must have enough antioxidants available that are ready to "neutralize" various free radicals or ROS the body is either exposed to or that it produces [2]. Dietary sources that are commonly known for their antioxidant properties include vitamin A, C, and E along with other antioxidants in carotenoids, lipoic acid, and phenolic compounds found in abundance in many plant products like fruits and vegetables $[2,17,66]$. Many of these dietary antioxidants are incorporated into the epidermal and dermal layers of human skin [15,17].

For example, studies have shown that consumption of the Mediterranean diet increased longevity and reduced age-related diseases, lowered levels of oxidative stress, and prevented cellular senescence in human epithelial cells [31]. Moreover, both dietary (via vitamins) and supplementation of antioxidant-rich ingredients (i.e., polyphenolic compounds like green tea or beta-carotene, lycopene, etc.) have been reported to improve parameters of skin structure, density and elasticity and protect against the damaging influence of UV exposure [64,67]. Conversely, Heinrich, in 2017, stated that while healthy nutritional intake and supplementation are recommended to increase the body's inherent UV protective mechanisms and/or improve skin health, this must not be a compensatory choice for an unhealthy diet [67]. In this regard, a recent study by Valacchi in 2015 showed that vitamin C mixtures prevented ozone-induced oxidative damage in human keratinoctyes [68].

Finally, nuclear-factor-erythroid 2-related factor $2(\mathrm{Nrf2})$ is a master regulator of the transcriptional response to oxidative stress, and it is structurally and functionally conserved from insects to humans [69]. Nrf2 plays a key role in the cellular defense against oxidative and xenobiotic stressors by its capacity to induce the expression of numerous genes, which encode detoxifying enzymes and antioxidant proteins that provide protection in endothelial cells, skin morphogenesis, wound repair, and skin cancer [70-73]. For example, Nrf2 deficiency or Nrf2-knockdown is known to cause lipid oxidation, inflammation, and extracellular matrix-protease expression (e.g., MMPs, cyclo-oxygenases (Cox) in UVA-irradiated skin fibroblasts or heat shock-induced human dermal fibroblasts [74,75]. In addition to dietary intake of vitamins and supplementation of antioxidant ingredients, other plant-derived compounds, such as equol, are known to stimulate $N f r 2$ and increase endogenous detoxifying enzymes and antioxidant production [2,73]. Finally, a recent review by Greenwald et al., 
in 2016, described a need for a Nfr2 activator in human skin to maintain dermal redox balance in modulating the Keap 1-Nrf2 pathway for antioxidant defense [76].

\section{What Is Equol?}

\subsection{Equol Is a Polyphenolic Compound}

Traditionally, equol is classified as a polyphenolic compound. Phenolics are a group of compounds having at least one hydroxyl group attached to an aromatic ring. The most high-profile polyphenolic molecule structurally related to equol known to the general public is resveratrol $[2,77,78]$ (see Figure 3). In higher plants, thousands of molecules have polyphenolic structures that are thought to be involved in protecting plants against ultraviolet radiation, aggression by pathogens, or stress-related responses, such as drought, or other extreme environmental conditions, such as temperatures (heat or cold) $[2,77,78]$.

Notably, both equol and resveratrol are known to be strong antioxidants when topically applied and the differences in orally administrated between these two polyphenolic molecules are reviewed elsewhere [2].

\subsection{Equol Is a Phytochemical}

Phyto means coming from, or related to, plants. Thus, equol (presumably S-equol) is present naturally in some plants, such as beans, cabbage, and lettuces, having a botanical origin $[2,78,79]$ (see Figure 3). It also has chemical or biological properties, such as being a very strong antioxidant, the ability to bind specifically the potent androgen 5alpha-dihydrotestosterone ( $5 \alpha$-DHT) with no affinity for a variety of other steroids, and it has an asymmetric carbon atom or chiral carbon that makes it structurally different from other polyphenolic compounds [2,78]. The asymmetric carbon is attached to four different atoms or groups of atoms, resulting in isomers or mirror image molecules that cannot be superimposed on each other [2] (see Figure 3). Notably, both S-equol and R-equol can specifically bind free $5 \alpha$-DHT $[2,79]$.

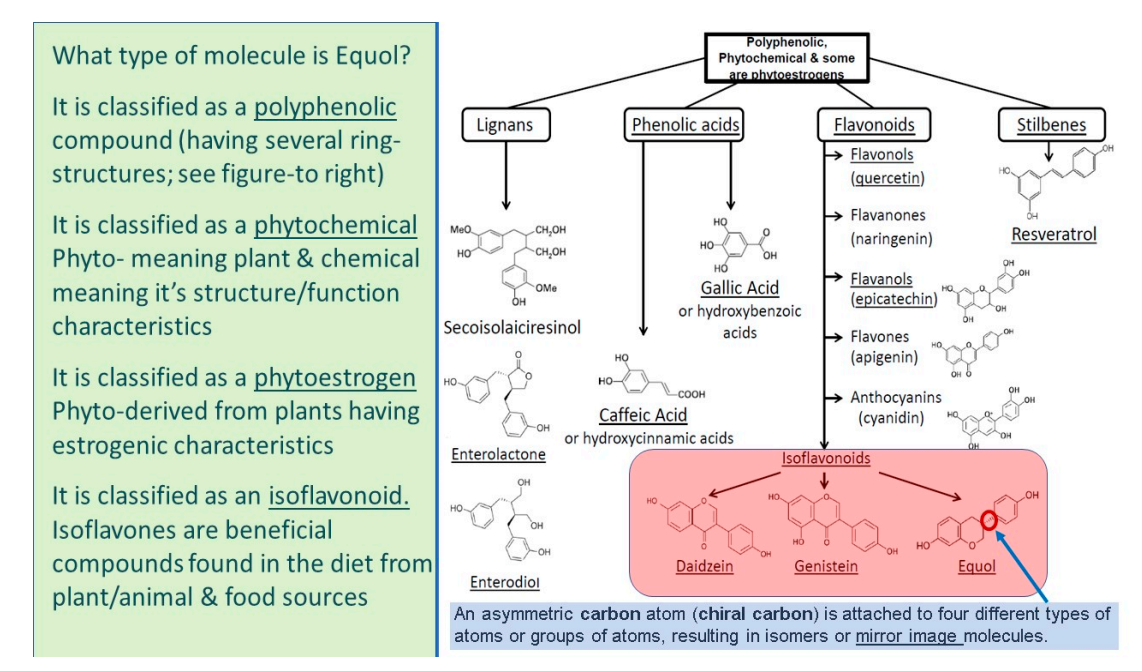

Figure 3. Equol's classifications, chemical structural and functional characteristics. "What type of molecule is Equol?" is displayed on the left-hand portion, which includes polyphenolic, phytochemical, phytoestrogen, and isoflavonoid classifications. On the right-hand portion, the polyphenolic classifications include the major lignans, phenolic acids, flavonoids, and stilbene categories, and the chemical structures are shown in reference to equol's isoflavonoid classification with its unique chiral carbon and, thus, mirror-image expression of isomers. 


\subsection{Equol Is a Phytoestrogen}

Phyto-derived compounds from plants may have estrogenic characteristics because they can bind to mammalian estrogen receptors and to estrogen-related receptor gamma (ERR gama) [2,78] (see Figure 3). While endogenous estrogenic hormones, such as $17 \beta$-estradiol, are steroids with a cyclo-hexane-phenantrene parent chemical structure that is derived from cholesterol, equol is not a steroid. However, equol and $17 \beta$-estradiol have similar chemical structures/confirmations and molecular weights $\left(\mathrm{C}_{15} \mathrm{H}_{14} \mathrm{O}_{3}\right.$ vs. $\mathrm{C}_{18} \mathrm{H}_{24} \mathrm{O}_{2} ; 242.3 \mathrm{~g} / \mathrm{mol}$ vs. $272.4 \mathrm{~g} / \mathrm{mol}$, respectively) [2]. Since equol has a chiral carbon, it can exist as two isomers, S-equol and R-equol. Remarkably, S-equol binds ER $\beta$ approximately $1 / 5$, as well as $17 \beta$-estradiol, while having low affinity for ER $\alpha[2,78,80]$. For example, the $\mathrm{Kd}$ for $17 \beta$-estradiol has been reported at $0.15 \mathrm{nM}$ for ER $\beta$, while the Ki for S-equol was $0.7 \mathrm{nM}$ as reported by Setchell at al. in 2005 and reviewed in 2017 [78,80]. Thus, S-equol is classified as a selective estrogen receptor modulator (SERM) with high affinity for ER $\beta$. Conversely, R-equol has weak affinity for either ER and, in general, has weak estrogenic properties, at best [2,78]. Additionally, racemic equol (exactly a 50\% mixture of the S- and R-isomers of equol) has been shown to bind and activate ERR gamma, which has been shown to be protective against inflammation and has anti-proliferative effects on prostate and breast cancer cells $[2,78,81,82]$. Finally, equol and cancer prevention was reviewed, in 2017, not only for its estrogenic and anti-estrogenic activities, but also for its antioxidant and anti-inflammatory properties [83].

\subsection{Equol Is an Isoflavonoid}

S-equol, which is a metabolite of daidzein (an isoflavone found in plant and food products), has been found in plant products such as beans, cabbage, lettuces, tofu, and other food and animal products, like eggs and cow's milk, as reviewed elsewhere [2,78] (see Figure 3). S-equol is an intestinal metabolite in animals and humans, when precursor compounds (like daidzein) are consumed but, in general, most humans do not generate S-equol concentrations at high levels [2,78,79]. Interestingly, until the equol hypothesis was proposed genistein, another polyphenolic/isoflavonoid molecule, was highly studied in the 1980s to the mid-1990s [2,78,79]. The equol hypothesis suggested that maintaining blood levels of S-equol at threshold concentrations (around 10 to $20 \mathrm{ng} / \mathrm{mL}$ ) would imply health benefits in humans, such as protection against breast and prostate cancer [78-80]. After this hypothesis was proposed a dramatic increase in research activity occurred that reported equol's beneficial properties for a variety of disorders [2,79]. Finally, equol's chemical name is: $4^{\prime}, 7$-isoflavandiol, which denotes its classification as an isoflavonoid.

\section{How Equol Protects Skin against Environmental Assaults}

Equol has been studied for more than 20 years [79,83]. However, more recently its novel application to skin health has occurred, where several reports using topical applications of equol have demonstrated improved human dermal parameters, such as: in in vitro (human dermal fibroblast cell cultures or human dermal organotypic cell cultures), in ex vivo (human dermal Franz cell testing and human skin gene microarray studies), and have shown proof of principle, proof of concept, and proof of mechanism(s), along with in vivo studies from human repeat insult patch test (RIPT) and applications in cosmetics, where more than 100,000 women have used topically-applied equol with great success $[2,78,84,85]$. In fact, equol is the only cosmetic ingredient, where in vitro gene expression biomarkers have been shown to correspond to protein expression levels validating that gene activation results in a parallel change in gene product or protein levels [86].

\subsection{Equol Is Delivered into Human Skin via a Unique "Reservoir" Delivery Mechanism}

Franz cell testing using tritiated equol penetration into human skin has shown: (1) the percutaneous absorption and; (2) skin content distribution among the epidermal and dermal compartments. Thus, the epidermal "reservoir" delivery mechanism of topically applied equol to the 
dermal layer over time has not been seen with other compounds, such as other polyphenolic molecules like resveratrol, along with the isoflavonoid genistein, or topical drugs, like $17 \beta$-estradiol [85]. For example, based upon the percutaneous absorption profile of equol through human skin it is presumably sequestered into the epidermal compartment due to its affinity to, and the abundance of, estrogen receptor beta (ER $\beta$ ) in keratinocytes and forms an equol "reservoir" that has a time-release prolife into the dermis with a primary absorption peak at approximately $8 \mathrm{~h}$ and a secondary peak at around $28 \mathrm{~h}$ [85]. This sustained release of topically-applied equol acts upon fibroblasts and promotes continued positive effects on skin health and addresses the issues of oxidative stress $[2,85]$. Undoubtedly, equol may enhance the skin's barrier function and cellular integrity via its topical application and sustained delivery mechanism $[12,82]$. In support of this notion, the recent report by Lademann et al., in 2016, showed that antioxidants positively influenced the barrier function of human skin [87]. For example, antioxidants significantly increased epidermal thickness, elasticity, and stratum corneum moisture content [87].

\subsection{Equol Increases Skin Antioxidant Defense and Stimulates Nrf2 Gene Expression}

In vitro studies have shown that equol itself is a strong antioxidant with greater capacity for neutralizing oxidants compared, in general, to genistein, vitamin $C$, or other polyphenolic compounds, like quercetin, that are known to counteract the damaging effects of oxidative stress or ROS [2,88-91]. In regards to ROS, previous studies have examined the role of antioxidants in dermal aging by oxidative stress production via gene expression analysis [91,92]. From gene array studies, equol has been shown to stimulate the following antioxidant enzymes in human skin, such as SOD 2 and thioredoxin reductase 1 (TXNRD 1) [84,85]. It is well established that SOD 2 and TXNRD 1 are known to protect against free radicals, oxidative stress, and UV-induced skin damage $[15,93]$. Furthermore, other investigators have reported the positive biological activities of equol that include the UV-protective antioxidant effects via the endogenous cutaneous antioxidant enzyme haem oxygenase (HO)-1 [94]. It is known from cardiovascular studies examining dietary isoflavones that haem oxygenase is a protector of lipid peroxidation and is part of the mitogen-activated protein kinase (MAPK) pathway that results in the activation of antioxidant genes/enzyme via the Nrf2/KEAP 1/ARE pathway [95]. Additionally, equol has been shown to stimulate the gene expression of the SH-rich detoxifying proteins, like metallothionein- $1 \mathrm{H}$ and metallothionein-2 $\mathrm{H}$, that protect against metal toxicity $[85,94]$. Finally, Widyarini et al. have shown that equol's photo-protective effect in mouse and human skin is dependent on metallothionein [96].

Furthermore, since $N r f 2$ activation is known to increase antioxidants gene expression of several proteins, equol has been shown to increase nuclear-factor-erythroid 2-related factor 2 ( $N r f 2$ ) expression [73]. This molecular mechanism has been described, where it involves the release of Nrf2 (transcription factor) from Keap 1 (its cytoplasmic binding protein) and subsequent binding to the antioxidant response element (ARE) that are present in the promoter region of genes for antioxidant proteins and enzymes [6,97]. Specifically, equol may increase Nrf2 levels and/or bind to the estrogen-responsive elements (EREs) in the promoter region the $\mathrm{Nrf2}$ gene and/or increase gene expression of other antioxidant genes [2,97]. Support for this described mechanism was demonstrated by Zhang et al. (2013) that showed S-equol protected against peroxide-induced endothelial cell apoptosis by activation of estrogen receptor and Nrf2/ARE signaling pathways [73]. Additionally, for another detoxifying protein, equol was reported to increase the expression of the xenobiotic metabolizing enzyme quinone reductase (both mRNA and protein levels) via similar molecular mechanisms involving ER $\beta$ and Nrf2 to that described above [98].

Therefore, in brief, equol itself is a very strong antioxidant, and, in turn, it can increase the levels of the master gene, $N r f 2$, which regulates the endogenous expression of detoxifying proteins and many other antioxidant enzymes that are involved in wound repair, protection against skin cancer, and where Nrf2 activation guards against dermal damage, from sunlight (ionizing radiation) and oxidative stress via ROS [2,69-73,76,99]. 


\subsection{Equol Increases Extracellular Matrix Proteins, Like Collagen, Elastin, and TIMP 1}

Since environmental pollutants are known to speed up the aging process by breaking down the vital extracellular matrix proteins like collagen and elastin, it is important to note the positive impact equol has on these structural and functional molecules, along with the enzymes that breakdown, especially, collagen. From gene array and human fibroblast cell culture experiments equol has been shown to significantly increase the gene and protein expression of collagen and elastin by approximately 2 -fold along with increasing tissue inhibitor of matrix metalloproteinase 1 (TIMP 1) by 5.4-fold (the protein that blocks the action of matrix metalloproteinase $(M M P)$ ) that is known to break down collagen (see Figure 4) [2,84].

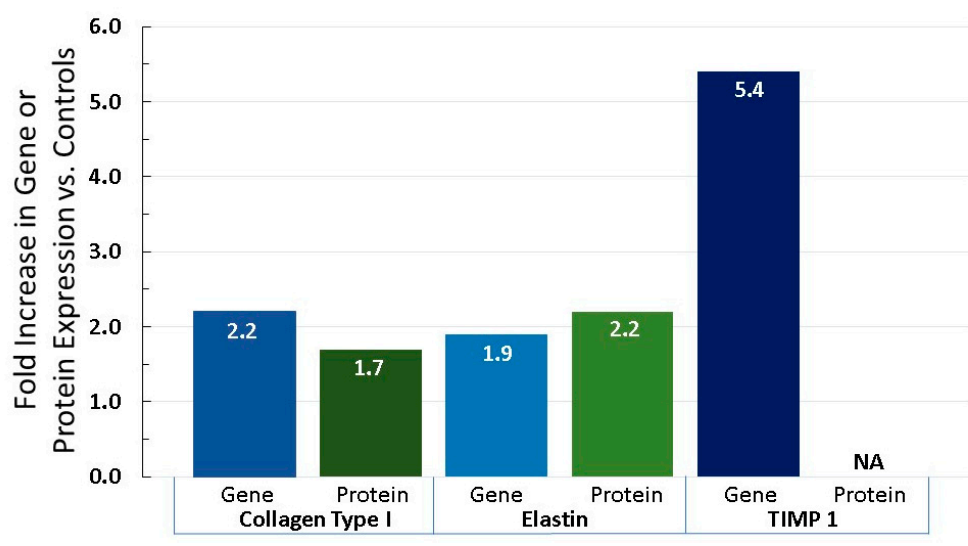

Figure 4. Equol increases the gene and protein expression of collagen type I, elastin, and tissue inhibitor of matrix metalloproteinase 1 (TIMP 1). In vitro cell culture, organotypic cell cultures, and gene array studies quantified the protein and gene expression levels of these dermal components when $10 \mathrm{nM}$ of equol was applied [84].

Additionally, when the enzyme gene expression of elastase (that breaks down elastin) and MMP 1 , $M M P$ 3, and MMP 9 (that are known to break down collagen and elastin fibers), were quantified, all were significantly inhibited by topically-applied equol in long-term organotypic cell cultures (see Figure 5) $[2,84,85]$. Particularly, where protein expression data were also available for $M M P 1$ and $M M P 3$, these values corresponded with, in general, the inhibition in gene expression levels (see Figure 5) [86].

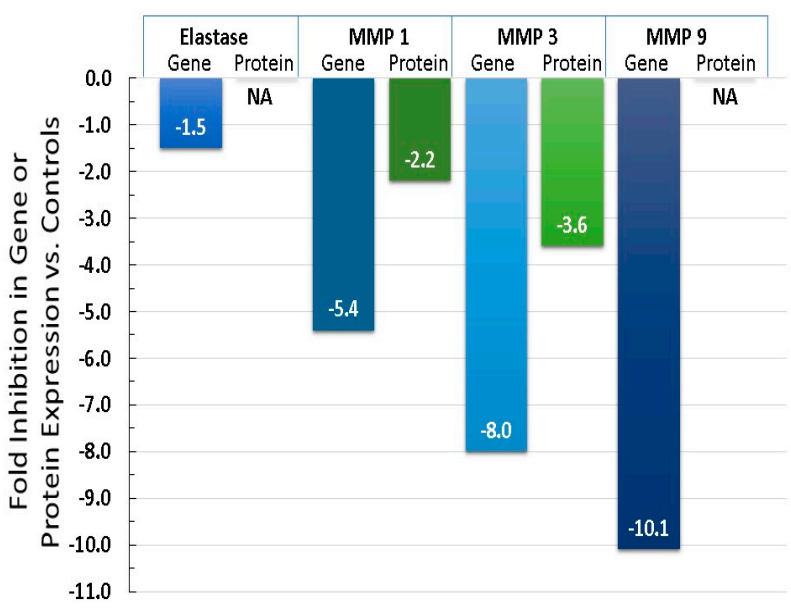

Figure 5. Equol inhibits the gene and protein expression of elastase and the matrix metalloproteinases (MMP 1, MMP 3, and MMP 9). In vitro cell culture, organotypic cell cultures, and gene array studies quantified the protein and gene expression levels of these dermal components when $10 \mathrm{nM}$ of equol was applied [84]. 


\subsection{Equol Decreases Oxidative Stress (ROS) and Inflammation}

The goal to slow down skin aging should include lifestyle changes (decreased sun exposure, diet, exercise, etc.) and treatments to decrease ROS production, in order to delay the onset/development of damaged cutaneous elements to support good dermal health. The formation of ROS is a widely accepted pivotal mechanism leading to skin aging (see Figure 6) $[2,13,14]$. For example, photoaging or extrinsic aging due to exposure to UV light along with assaults from environmental pollutants (such as particles, wind or cold) trigger oxidative stress and the formation of ROS that damages DNA, mitochondrial function, protein, lipids, and results in the declination of antioxidant levels [2,13,14]. Additionally, ROS activates AP-1 and suppresses TGF beta to decrease pro-collagen synthesis, while, at the same time, ROS increases MMP production (to break down collagen fibers) and also activates NF-KB to stimulate the inflammatory response that feeds back in a positive manner to generate more ROS (see Figure 6) [2].

Data obtained from cell culture (primary or organotypic), molecular, and gene expression/array methods have examined equol's influence on oxidative stress along with various biomarkers at different cascade steps/events that lead to damaged skin [2]. First, activator protein1 (AP-1) is a nuclear transcription element that is part of the oxidative stress cascade. AP-1 is known to block the positive pro-collagen actions of transforming growth factor- $\beta 1$ [100]. In this regard, Kang et al., in 2007, reported that the anti-tumor effects of equol are due to the inhibition of cell transformation by the MEK signaling pathway by blocking AP-1 [101]. Equol displayed a dose-dependently attenuated TPA-induced activation of $A P-1$, whereas, daidzein did not exert any effect when tested at the same concentrations [102]. Finally, ER $\beta$ signaling has been shown to protect against transplanted skin tumor growth in mice, which implicated a common mechanism of how the blocked AP-1 actions by equol reported by Kang et al. may be mediated [101,102]. Additionally, along with ROS's known direct stimulation of MMPs, AP-1 is also known to induce MMPs in human skin that, in turn, activates collagen degradation $[2,103]$.

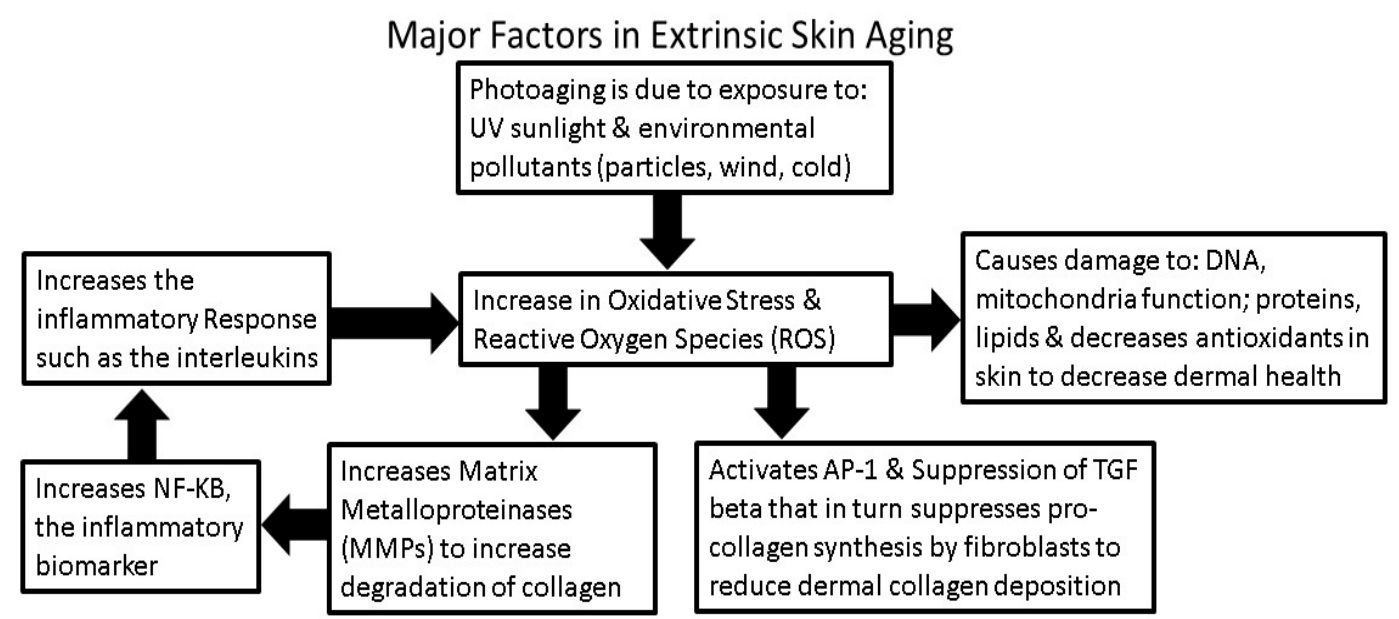

Figure 6. The major factors of extrinsic skin aging include: photoaging and environmental pollutants that, in turn, increase oxidative stress (ROS). The cascade of events associated with ROS production are shown which results in decreased skin antioxidant levels, the degradation of collage, and the activation of the inflammatory response. Redrawn, in part, from [2] with permission.

Next, the pro-inflammatory transcription factor NF-kappB (NF-KB) has been studied for more than 25 years and is known to be expressed in all cell types, where it is involved in the oxidative stress mechanism by the expression of numerous genes, such as the cytokines, and plays a major role in the pathology of inflammatory disease [104,105]. Equol has been shown to inhibit NF-KB in macrophages and block the production of free radicals like nitric oxide (NO) [106,107]. Additionally, 
since NF-KB is a pro-inflammatory agent, topical equol treatment in human skin via gene array studies have demonstrated that interleukin (IL) levels were significantly inhibited (such as $I L-I, I L-6, I L-8$ as well as cyclo-oxygenase $1(\mathrm{COX}-1))$ [84,85]. Additionally, tumor necrosis factor receptor levels were significantly inhibited by equol when compared to controls $[84,85]$.

Finally, since equol can be expressed as isomers, the type of equol tested (racemic, S-equol or R-equol) has been examined in a comprehensive investigation using PCR/mRNA quantification methods of human skin gene expression. In general, R-equol and/or racemic were more potent compared to S-equol in the obtained results for various human skin biomarkers [85]. For example, only three genes displayed the greatest significant expression by S-equol, whereas 16 genes displayed the greatest significant levels (either stimulation or inhibition) by R-equol and/or racemic equol, such as extracellular matrix proteins (i.e., collagen and elastin), nerve growth factor, aging genes (FOS, 100 A8 and A9 calcium-binding proteins, 5alpha-reductase type 1, and matrix metalloproteinases (1, 3, and 9)), and the inflammatory genes (e.g., interleukin-1 alpha, interleukin-6, and cyclooxygenase-1). Also, collagen type I expression in fibroblasts was greater with racemic versus S-equol treatment at 1 and $10 \mathrm{nM}$.

\section{Conclusions}

In brief, this short review covers the perception of skin sensitivities from environmental causes, such as toxins and pollutants in the air, and dermal assaults from wind and cold seasonal temperature exposure, along with the influence of diet on dermal health and, especially, antioxidant enhancement. All of these factors are associated with the generation of ROS, and this information is discussed in reference to skin antioxidant defense characteristics and dermal damage caused by inflammation and stress. In this regard, environmental pollution worldwide has generated a high demand for anti-pollution personal care products to protect the skin against the daily exposure of airborne toxins and various other assaults, like UV light, wind, and seasonal cold temperatures. Consumers are demanding anti-aging ingredients with enhanced antioxidant defense and protection against oxidative stress (ROS). Many major cosmetic companies have anti-pollution personal care products, but, in general, the products are formulated with commonly used active ingredients that have been in the marketplace for some time and have been retooled using marketing strategies to address current environmental pollution treatments to improve dermal health. Equol is a botanical compound with polyphenolic chemical characteristics found in plant and food products, and it is also classified as an isoflavonoid [12,76]. Moreover, equol appears to address the need as a new active ingredient in personal care products to protect against pollution assaults by increasing antioxidant defense, while inhibiting oxidative stress and inflammation [2,78]. Separate sections covering equol's enhanced: (a) delivery mechanism into human skin; (b) antioxidant effects via Nrf2 activation; (c) effects on extracellular matrix proteins like collagen and elastin; and (d) protection against oxidative stress and inflammation were presented. In fact, equol has been compared to other botanical actives, like resveratrol, and it appears to be an exceptional choice for potential incorporation into human skin applications, especially for women, due to its multiple positive actions to improve dermal health $[2,78,108]$.

Acknowledgments: This study/review was supported, in part, by LS/TTO funding, 19-2215 at Brigham Young University.

Author Contributions: The author contributed to the research, writing, generation of the figures and editing of this manuscript.

Conflicts of Interest: The author declares no corporate/business, funding or founder sponsor conflict of interest in the decision of the data/research presented in this review and regarding the publication of this manuscript. The author in an inventor on equol patents (U.S. and worldwide) on various health applications.

\section{References}

1. Farage, M.A.; Miller, K.W.; Elsner, P.; Maibach, H.I. Intrinsic and extrinsic factors in skin ageing: A review. Int. J. Cosmet. Sci. 2008, 30, 87-95. [CrossRef] [PubMed]

2. Lephart, E.D. Skin aging and oxidative stress: Equol's anti-aging effects via biochemical and molecular mechanisms. Ageing Res. Rev. 2016, 31, 36-54. [CrossRef] [PubMed] 
3. Katta, R.; Desai, S.P. Diet and dermatology, the role of dietary intervention in skin disease. J. Clin. Aesthet. Dermatol. 2014, 7, 46-51. [PubMed]

4. Farage, M.A. Perceptions of sensitive skin: Changes in perceived severity and associations with environmental causes. Contact Dermat. 2008, 59, 226-232. [CrossRef] [PubMed]

5. Farage, M.A.; Miller, K.W.; Wippel, A.M.; Berardesca, E.; Misery, L.; Mailbach, H. Sensitive skin in the United States: Survey of regional differences. Family Med. Med. Sci. Res. 2013, 2, 3. [CrossRef]

6. Misery, L. Neuropsychiatric factors in sensitive skin. Clin. Dermatol. 2017, 35, 281-284. [CrossRef] [PubMed]

7. Anderson, R.R. Cosmegizmoceuticals: The Physics and Chemistry of Looking Better. In Proceedings of the Society of Cosmetic Chemists Annual Meeting, New York, NY, USA, 6-7 December 2012; Volume 43.

8. Kligman, A.M.; Koblenzer, C. Demographics and psychological implications for the aging population. Dermatol. Clin. 1997, 15, 549-553. [CrossRef]

9. Al-Gubory, K.H. Environmental pollutants and lifestyle factors induce oxidative stress and poor prenatal development. Reprod. Biomed. Online 2014, 29, 17-31. [CrossRef] [PubMed]

10. Baynes, J.W. Role of oxidative stress in development of complications in diabetes. Diabetes 1991, 40, 405-412. [CrossRef] [PubMed]

11. Uttara, B.; Singh, A.V.; Zamboni, P.; Mahajan, R.T. Oxidative stress and neurodegenerative diseases: A review of upstream and downstream antioxidant therapeutic options. Curr. Neuropharmacol. 2009, 7, 65-74. [CrossRef] [PubMed]

12. Pohanka, M. Role of oxidative stress in infectious diseases. A review. Folia Microbiol. 2013, 58, 503-513. [CrossRef] [PubMed]

13. Kammeyer, A.; Luiten, R.M. Oxidative events and skin aging. Ageing Res. Rev. 2015, 21, 16-29. [CrossRef] [PubMed]

14. Natarajan, V.T.; Ganju, P.; Ramkumar, A.; Grover, R.; Gokhale, R.S. Multifaceted pathways protect human skin from UV radiation. Nat. Chem. Biol. 2014, 10, 542-551. [CrossRef] [PubMed]

15. Shindo, Y.; Witt, E.; Han, D.; Epstein, W.; Packer, L. Enzymic and non-enzymic antioxidants in epidermis and dermis in human skin. J. Investig. Dermayol. 1994, 102, 122-124. [CrossRef]

16. Krishnamurthy, P.; Wadhwani, A. Antioxidant Enzymes and Human Health, Chapter 1; El-Missiry, M.A., Ed.; Antioxidant Enzyme-InTech Science, Technology \& Medicine: Vienna, Austria, 2012; pp. 4-18. [CrossRef]

17. Pullar, J.M.; Carr, A.C.; Vissers, M.C.M. The role of vitamin C in skin health. Nutrients 2107, 9, 866. [CrossRef] [PubMed]

18. Anderson, A.; Bowman, A.; Boulton, S.J.; Manning, P. A role for human mitochondrial complex II in the production of reactive oxygen species in human skin. Redox Biol. 2014, 2, 1016-1022. [CrossRef] [PubMed]

19. Meadows, C.; Moore, D.J.; Moore, D.M.; Draelos, Z.D.; Kern, D. Age-related NADH oxidase (arNOX)catalyzed oxidative damage to skin protein. Arch. Dermatol. Res. 2014, 306, 645-652. [CrossRef] [PubMed]

20. Quan, C.; Cho, M.K.; Perry, D.; Quan, T. Age-associated reduction of cell spreading induces mitochondrial DNA common deletion by oxidative stress in human skin dermal fibroblasts: Implication for human skin connective tissue aging. J. Biomed. Sci. 2015, 22, 62. [CrossRef] [PubMed]

21. Tulah, A.S.; Birch-Machin, M.A. Stressed out mitochondria: The role of mitochondria in ageing and cancer focusing on strategies and opportunities in human skin. Mitochondrion 2013, 13, 444-453. [CrossRef] [PubMed]

22. Valacchi, G.; Perorelli, A.; Cervellati, F.; Cervellati, C.; Maioli, F. Cutaneous responses to environmental stressors. Ann. N. Y. Acad. Sci. 2012, 1271, 75-81. [CrossRef] [PubMed]

23. Walker, S.L.; Hawk, J.L.M.; Young, A.R. Acute and chronic effects of ultraviolet radiation on the skin. In Fitzpatrick's Dermatology in General Medicine, 6th ed.; Freedberg, I.M., Eisen, A.Z., Wolff, K.F., Austen, L.A., Goldsmith, L.A., Katz, S.I., Eds.; McGraw-Hill: New York, NY, USA, 2003; pp. 1275-1282.

24. Wlaschek, M.; Tantcheva-Poór, I.; Naderi, L.; Ma, W.; Schneider, L.A.; Razi-Wolf, Z.; Schüller, J.; Scharffetter-Kochanek, K. Solar UV irradiation and dermal photoaging. J. Photochem. Photobiol. B 2001, 63, 41-51. [CrossRef]

25. Birch-Machin, M.A.; Swalwell, H. How mitochondria record the effects of UV exposure and oxidative stress using human skin as a model tissue. Mutagenesis 2010, 25, 101-107. [CrossRef] [PubMed]

26. Lehmuskallio, E.; Hassi, J.; Kettunen, P. The skin in the cold. Int. J. Circumpolar Health 2002, 61, $277-286$. [CrossRef] [PubMed]

27. Makinen, T.A.; Hassi, J. Health problems in cold work. Ind. Health 2009, 47, 207-220. [CrossRef] [PubMed] 
28. Briggs, A.G.S.; Gillespie, T.J.; Brown, R.D. Measuring facial cooling in outdoor windy winter conditions: An exploratory study. Int. J. Biometeorol. 2017, 61, 1831-1835. [CrossRef] [PubMed]

29. Schmidt, M.C.; Askew, E.W.; Roberts, D.E.; Prior, R.L.; Ensign, W.Y., Jr.; Hesslink, R.E., Jr. Oxidative stress in humans training in a cold, moderate altitude environment and their response to a phytochemical antioxidant supplement. Wilderness Environ. Med. 2002, 13, 94-105. [CrossRef]

30. Martarelli, D.; Cocchioni, M.; Scuri, S.; Spataro, A.; Pompei, P. Cold exposure increases exercise-induced oxidative stress. J. Sports Med. Phys. Fit. 2011, 51, 299-304.

31. Naidoo, K.; Birch-Machin, M.A. Oxidative stress and ageing: The influence of environmental pollution, sunlight and diet on skin. Cosmetics 2017, 4, 4. [CrossRef]

32. Hamer, M.A.; Pardo, L.M.; Jacobs, L.C.; Ikram, M.A.; Laven, J.S.; Kayser, M.; Hollestein, L.M.; Gunn, D.A.; Nijsten, T. Lifestyle and physiological factors associated with facial wrinkling in men and women. J. Investig. Dermatol. 2017, 137, 1692-1699. [CrossRef] [PubMed]

33. Hodges, A.L.; Walker, D.K. Skin care for women. Nurs. Womens Health 2017, 20, 609-613. [CrossRef] [PubMed]

34. Vierkotter, A. Environmental pollution and skin aging. Hautarzt 2011, 62, 577-578. [PubMed]

35. Kelly, F.J. Oxidative stress: Its role in air pollution and adverse health effects. Occup. Environ. Med. 2003, 60, 612-616. [CrossRef] [PubMed]

36. Pope, C.A.; Dockery, D.W.; Spengler, J.D.; Raizenne, M.E. Respiratory health and PM10 pollution-A daily time-series analysis. Am. Rev. Respir. Dis. 1991, 144, 668-674. [CrossRef] [PubMed]

37. Lodovici, M.; Bigagli, E. Oxidative stress and air pollution exposure. J. Toxicol. 2011, 2011, 487074. [CrossRef] [PubMed]

38. Delfino, R.J.; Staimer, N.; Vaziri, N.D. Air pollution and circulating biomarkers of oxidative stress. Air Qual. Atmos. Health 2011, 4, 37-52. [CrossRef] [PubMed]

39. Nikolic, M.; Nikic, D.; Arandjelovic, M. Air pollution and skin effects in children. J. Environ. Prot. Ecol. 2010, 11, 1215-1221.

40. Krutmann, J.; Bouloc, A.; Sore, G.; Bernard, B.A.; Passeron, T. The skin aging exposome. J. Dermatol. Sci. 2017, 85, 152-161. [CrossRef] [PubMed]

41. Puri, P.; Nandar, S.K.; Kathuria, S.; Ramesh, V. Effects of air pollution on the skin. A review. Indian J. Dermatol. Venereol. Leprol. 2017, 83, 415-423. [PubMed]

42. Lanuti, E.L.; Kirsner, R.S. Effects of pollution on skin aging. J. Investig. Dermatol. 2010, 130, 2696. [CrossRef] [PubMed]

43. Vierkötter, A.; Schikowski, T.; Ranft, U.; Sugiri, D.; Matsui, M.; Krämer, U.; Krutmann, J. Airborne particle exposure and extrinsic skin aging. J. Investig. Dermatol. 2010, 130, 2719-2726. [CrossRef] [PubMed]

44. Senthilkumar, P.K.; Klingelhutz, A.J.; Jacobus, J.A.; Lehmler, H.; Robertson, L.W.; Ludewig, G. Airborne polychlorinated biphenyls (PBCs) reduce telomerase activity and shorten telomere length in immortal human skin keratinocytes (HaCat). Toxicol. Lett. 2011, 204, 64-70. [CrossRef] [PubMed]

45. Poljšak, B.; Dahmane, R. Free radicals and extrinsic aging. Dermatol. Res. Pract. 2012, 2012, 135206. [CrossRef] [PubMed]

46. Pedala, P.; Boccellino, M.; La Porta, R.; Napolitano, M.; Minutolo, P.; Sgro, L.A.; Zei, F.; Sannolo, N.; Quagliuolo, L. Interaction between combustion-generated organic nanoparticles and biological systems: In vitro study of cell toxicity and apoptosis in human keratinocytes. Nanotoxicology 2012, 6, 338-352.

47. Bakke, J.V.; Wieslander, G.; Norback, D.; Moen, B.E. Eczema increases susceptibility to PM10 in office indoor environments. Arch. Environ. Occup. Health 2012, 67, 15-21. [CrossRef] [PubMed]

48. Kamide, R.; Misery, L.; Perez-Cullell, N.; Sibaud, V.; Taieb, C. Sensitive skin evaluation in the Japanese population. J. Dermatol. 2013, 40, 177-181. [CrossRef] [PubMed]

49. Ahn, K. The role of air pollutants in atopic dermatitis. J. Allergy Clin. Immunol. 2014, 134, 993-999. [CrossRef] [PubMed]

50. Krutmann, J.; Liu, W.; Li, L.; Pan, X.; Crawford, M.; Sore, G.; Seite, S. Pollution and skin: From epidermiological and mechanistic studies to clinical implications. J. Dermatol. Sci. 2014, 76, 163-168. [CrossRef] [PubMed]

51. Li, M.; Vierkötter, A.; Schikowski, T.; Hüls, A.; Matsul, M.S.; Deng, B.; Ma, C.; Ren, A.; Zhang, J.; Tan, J.; et al. Epidemiological evidence that indoor air pollution from cooking with solid fuels accelerates skin aging in Chinese women. J. Dermatol. Sci. 2015, 79, 148-154. [CrossRef] [PubMed] 
52. Kim, Y.-K.; Kim, H.; Lim, D.-H.; Lee, Y.-K.; Kim, J.H. Effects of indoor air pollutants on atopic dermatitis. Int. J. Environ. Res. Public Health 2016, 13, 1220. [CrossRef] [PubMed]

53. Pan, T.L.; Wang, P.W.; Aljuffali, A.; Huang, C.T.; Lee, C.W.; Fang, J.Y. The impact of urban particulate pollution on skin barrier function and the subsequent drug absorption. J. Dermatol. Sci. 2015, 78, 51-60. [CrossRef] [PubMed]

54. Roberts, W.E. Pollution as a risk factor for the development of melasma and other skin disorders of facial hyperpigmentation-is there a case to be made? J. Drugs Dermatol. 2015, 14, 337-341. [PubMed]

55. Kim, K.E.; Cho, D.; Park, H.J. Air pollution and skin diseases: Adverse effects of airborne particulate matter on various skin diseases. Life Sci. 2016, 152, 126-134. [CrossRef] [PubMed]

56. Nakamura, M.; Morita, A.; Seitè, S.; Haarmann-Stemmann, T.; Grether-Beck, S.; Krutmann, J. Environmentinduced lentigines: Formation of solar lentigines beyond ultraviolet radiation. Exp. Dermatol. 2015, 24, 407-411. [CrossRef] [PubMed]

57. Peng, F.; Xue, C.H.; Hwang, S.K.; Li, W.H.; Chen, Z.; Zhang, J.Z. Exposure to fine particulate matter associated with senile lentingo in Chinese women: A cross-sectional study. J. Eur. Acad. Dermatol. Venereol. 2017, 31, 355-360. [CrossRef] [PubMed]

58. Qiao, Y.; Li, Q.; Du, H.-Y.; Wang, Q.-W.; Huang, Y.; Liu, W. Airborne polycyclic aromatic hydrocarbons trigger human skin cells aging through aryl hydrocarbon receptor. Biochem. Biophys. Res. Commun. 2017, 488, 445-452. [CrossRef] [PubMed]

59. Kim, H.-J.; Bae, I.-H.; Son, E.D.; Park, J.; Cha, N.; Na, H.-W.; Jung, C.; Go, Y.-S.; Kim, D.-Y.; Lee, T.R.; Shin, D.W. Transcriptome analysis of airborne PM 2.5-induced detrimental effects on human keratinocytes. Toxicol. Lett. 2017, 273, 26-35. [CrossRef] [PubMed]

60. Mancebo, S.E.; Wang, S.Q. Recognizing the impact of ambient air pollution on skin health. J. Eur. Acad. Dermatol. Venereol. 2015, 29, 2326-2332. [CrossRef] [PubMed]

61. Koohgoli, R.; Hudson, L.; Naidoo, K.; Wilkinson, S.; Chavan, B.; Birch-Machin, M.A. Bad air gets under your skin. Exp. Dermatol. 2017, 26, 384-387. [CrossRef] [PubMed]

62. Valavanidis, A.; Vlahogianni, T.; Dassenakis, M.; Scoullos, M. Molecular biomarkers of oxidative stress in aquatic organisms in relation to toxic environmental pollutants. Ecotoxicol. Environ. Saf. 2006, 64, 178-189. [CrossRef] [PubMed]

63. Lushchak, V.I. Environmentally induced oxidative stress in aquatic animals. Aquat. Toxicol. 2011, 101, 13-30. [CrossRef] [PubMed]

64. Draelos, Z.D. Aging Skin: The role of diet: Facts and controversies. Clin. Dermatol. 2013, 31, $701-706$. [CrossRef] [PubMed]

65. Rona, C.; Berardesca, E. Aging skin and food supplements: The myth and the truth. Clin. Dermatol. 2008, 26, 641-647. [CrossRef] [PubMed]

66. Lee, J.; Koo, N.; Min, D.B. Reactive oxygen species, aging and antioxidative nutraceuticals. Compr. Rev. Food Sci. Food Saf. 2004, 3, 21-33. [CrossRef]

67. Heinrich, U. Anti-aging by nutricosmetics. Aktuelle Dermatol. 2017, 43, 427-430.

68. Valacchi, G.; Sticozzi, C.; Belmonte, G.; Cervellati, F.; Demaude, J.; Chen, N.; Krol, Y.; Oresajo, C. Vitamin C compound mixtures prevent ozone-induced oxidative damage in human keratinocytes as initial assessment of pollution protection. PLOS ONE 2015, 10, e0131097. [CrossRef] [PubMed]

69. Lacher, S.E.; Lee, J.S.; Wang, X.; Campbell, M.R.; Bell, D.A. Beyond antioxidant genes in the ancient Nrf2 regulatory network. Free Radic. Biol. Med. 2015, 88, 452-465. [CrossRef] [PubMed]

70. Beyer, T.A.; Keller, U.; Braun, S.; Schafer, M.; Werner, S. Roles and mechanisms of action of the Nrf2 transcription factor in skin morphogenesis, wound repair and skin cancer. Cell Death Differ. 2007, 14, 1250-1554. [CrossRef] [PubMed]

71. Greenwald, M.B.Y.; Frusic-Zlotkin, M.; Soroka, Y.; Sasson, S.B.; Bianco-Peled, H.; Bitton, R.; Kohen, R. Nitroxide delivery system for Nrf2 activation and skin protection. Eur. J. Pharm. Biopharm. 2015, 94, $123-134$. [CrossRef] [PubMed]

72. Sekhar, K.R.; Freeman, M.L. Nrf2 promotes survival following exposure to ionizing radiation. Free Radic. Biol. Med. 2015, 88, 268-274. [CrossRef] [PubMed]

73. Zhang, T.; Liang, X.Y.; Shi, L.Y.; Wang, L.; Chen, J.L.; Kang, C.; Zhu, J.D.; Mi, M.T. Estrogen receptor and $\mathrm{PI} 3 \mathrm{~K} /$ Akt signaling pathway involvement in S-equol-induced activation of Nrf2/ ARE in endothelia cells. PLoS ONE 2013, 8, e79075. [CrossRef] 
74. Gruber, F.; Ornelas, C.M.; Karner, S.; Narzt, M.S.; Nagelreiter, M.I.; Gschwandtner, M.; Bochkov, V.; Tschachler, E. Nrf2 deficiency causes lipid oxidation, inflammation, and matrix-protease expression in DHA-supplemented and UVA-irradiated skin fibroblasts. Free Radic. Biol. Med. 2015, 88, 439-451. [CrossRef] [PubMed]

75. Park, G.; Oh, M.S. Acceleration of heat shock-induced collagen breakdown in human dermal fibroblasts with knockdown of NF-E2-related factor 2. BMB Rep. 2015, 48, 467-472. [CrossRef] [PubMed]

76. Greenwald, M.B.-Y.; Ben-Sasson, S.; Blanco-Peled, H.; Kohen, R. Skin redox balance maintenance: The need for a Nrf2-activator delivery system. Cosmetics 2016, 3, 1. [CrossRef]

77. Park, E.-J.; Pezzuto, J.M. The pharmacology of resveratrol in animals and humans. Biochim. Biophys. Acta 2015, 1852, 1071-1113. [CrossRef] [PubMed]

78. Lephart, E.D. Resveratrol, $4^{\prime}$ Acetoxy Resveratrol, R-Equol, Racemic Equol or S-Equol as Cosmeceuticals to Improve Dermal Health. Int. J. Mol. Sci. 2017, 18, 1193. [CrossRef] [PubMed]

79. Setchell, K.D.R.; Clerici, C. Equol: History, chemistry, and formation. J. Nutr. 2010, 140, 1355S-1362S. [CrossRef] [PubMed]

80. Setchell, K.D.R.; Clerici, C.; Lephart, E.D.; Cole, S.J.; Heenan, C.; Castellani, D.; Wolfe, B.E.; Nechemias-Zimmer, L.; Brown, N.M.; Lund, T.D.; et al. S-equol, a potent ligand for estrogen receptor $\beta$, is the exclusive enantiomeric form of the soy isoflavone metabolite produced by human intestinal bacterial flora. Am. J. Clin. Nutr. 2005, 81, 1072-1079. [PubMed]

81. Krahn-Bertil, E.; Bolzinger, M.A.; Andre, V.; Orly, I.; Kanitakis, J.; Rousselle, P.; Damour, O. Expression of estrogen-related receptor gamma (ERRgamma) in human skin. Eur. J. Dermatol. 2008, 18, 427-432. [PubMed]

82. Hirvonen, J.; Rajalin, A.M.; Wohlfart, G.; Adlercreutz, H.; Wähälä, K.; Aarnisalo, P. Transcriptional activation of estrogen-related receptor gamma (ERRgamma) is stimulated by the phytoestrogen equol. J. Steroid Biochem. Mol. Biol. 2010, 123, 46-57. [CrossRef] [PubMed]

83. Liliana, M.; Rusu, T.; Wang, T.Y.; Park, J.B.; Clapa, D. Soy-derived microbial metabolite equol in cancer prevention. Agric. Sci. Pract. 2017, 1-2, 5-20.

84. Gopaul, R.; Knaggs, H.; Lephart, E.D. Biochemical investigation and gene analysis of equol: A plant and soy-derived isoflavonoid with anti-aging and antioxidant properties with potential human skin applications. Biofactors 2012, 38, 44-52. [CrossRef] [PubMed]

85. Lephart, E.D. Protective effects of equol and their polyphenolic isomers against dermal aging: Microarray/ protein evidence with clinical implications and unique delivery into human skin. Pharm. Biol. 2013, 51, 1393-1400. [CrossRef] [PubMed]

86. Lephart, E.D. Human Skin Gene Expression Doesn't Correlate with Protein Expression? Unless Both Parameters Are Quantified. J. Cosmet. Dermatol. 2017. [CrossRef] [PubMed]

87. Lademann, J.; Vergou, T.; Darvin, M.; Patzelt, A.; Meinke, M.; Voit, C.; Papakostas, D.; Zastrow, L.; Sterry, W.; Doucet, $\mathrm{O}$. Influence of topical, systematic and combined application of antioxidants on barrier properties of the human skin. Skin Pharm. Physiol. 2016, 29, 41-46. [CrossRef] [PubMed]

88. Arora, A.; Nair, M.G.; Strasburg, G.M. Antioxidant activities of isoflavones and their biological metabolites in a liposomal system. Arch. Biochem. Biophys. 1988, 356, 133-141. [CrossRef] [PubMed]

89. Mitchell, J.H.; Gardner, P.T.; McPhail, D.B.; Morrice, P.C.; Collins, A.R.; Duthie, G.C. Antioxidant efficacy of phytoestrogens in chemical and biological model systems. Arch. Biochem. Biophys. 1998, 360, 142-148. [CrossRef] [PubMed]

90. Rufer, C.E.; Kulling, S.E. Antioxidant activity of isoflavones and their major metabolites using different in vitro assays. J. Agric. Food Chem. 2006, 54, 2926-2931. [CrossRef] [PubMed]

91. Avantaggiato, A.; Bertuzzi, G.; Vitiello, U.; Iannucci, G.; Pasin, M.; Cervelli, V.; Carinci, F. Role of antioxidants in dermal aging: An in vitro study by q-RT-PCR. Aesthet. Plast. Surg. 2014, 38, 1011-1016. [CrossRef] [PubMed]

92. Pandel, R.; Poljsak, B.; Godic, A.; Dahmane, R. Skin photoaging and the role of antioxidants in its prevention. ISRN Dermatol. 2013, 2013, 930164. [CrossRef] [PubMed]

93. Velarde, M.C.; Flynn, J.M.; Day, N.U.; Melvo, S.; Campisi, J. Mitochondrial oxidative stress caused by SOD deficiency promotes cellular senescene and aging phenotypes in the skin. Aging 2012, 4, 3-12. [CrossRef] [PubMed] 
94. Widyarini, S.; Domanski, D.; Painter, N.; Reeve, V.E. Photoimmune protective effect of the phytoestrogenic isoflavonoid equol is partially due to its antioxidant activities. Photochem. Photobiol. Sci. 2012, 11, 1186-1192. [CrossRef] [PubMed]

95. Mann, G.E.; Bonacasa, B.; Ishii, T.; Siow, R.C.M. Targeting the redox sensitive Nrf2-Keep1 defense pathway in cardiovascular disease: Protection afforded by dietary isoflavones. Curr. Opin. Pharmacol. 2009, 9, 139-145. [CrossRef] [PubMed]

96. Widyarini, S.; Allanson, M.; Gallagher, N.L.; Pedley, J.; Boyle, G.M.; Parsons, P.G.; Whiteman, D.C.; Walker, C.; Reeve, V.E. Isoflavonoid photoprotection in mouse and human skin is dependent on metallothionein. J. Investig. Dermatol. 2006, 126, 198-204. [CrossRef] [PubMed]

97. Jackson, R.L.; Greiwe, J.S.; Schwen, R.J. S-equol, an antioxidant metabolite of soy dadizein, and oxidative stress in aging: A focus on skin and the cardiovascular system. In Aging: Oxidative Stress and Dietary Antioxidants; Elsevier Inc.: London, UK, 2014; pp. 145-155.

98. Froyen, E.B.; Steinberg, F.M. Soy isoflavones increase quinone reductase in heap-1c1c7 cells via estrogen receptor beta and nuclear factor erythroid 2-related factor 2 binding to the antioxidant response element. J. Nutr. Biochem. 2011, 22, 843-848. [CrossRef] [PubMed]

99. Rabe, J.H.; Mamelak, A.J.; McElgunn, P.J.; Morison, W.L.; Sauder, D.N. Photoaging: Mechanisms and repair. J. Am. Acad. Dermatol. 2006, 55, 1-19. [CrossRef] [PubMed]

100. Fisher, G.J.; Datta, S.C.; Taylor, H.S. Molecular basis of sun induced premature skin aging and retionoid antagonism. Nature 1996, 379, 335-339. [CrossRef] [PubMed]

101. Kang, N.J.; Lee, K.W.; Rogozin, E.A.; Cho, Y.-Y.; Heo, Y.-S.; Bode, A.M.; Lee, H.J.; Dong, Z. Equol inhibits neoplastic cell transformation by targeting the MEK/ERK/p90RSK/ activator protein-1 pathway. J. Biol. Chem. 2007, 45, 32856-32866. [CrossRef] [PubMed]

102. Cho, J.-L.; Allanson, M.; Domanski, D.; Arun, S.J.; Reeve, V.E. Oestrogen receptor-beta signaling protects against transplanted skin tumor growth in the mouse. Photochem. Photobiol. Sci. 2010, 9, 608-614. [CrossRef] [PubMed]

103. Huang, C.; Schmid, P.C.; Ma, W.Y.; Schmidt, H.H.; Dong, Z. Phosphatidylinositol-3 kinase is necessary for 12-O-tetradecanoylphorbol 13-acetate-induced cell transformation and activated protein 1 activation. J. Biol. Chem. 1997, 272, 4187-4194. [CrossRef] [PubMed]

104. Gupta, S.C.; Sundaram, C.; Reuter, S.; Aggarwal, B.B. Inhibiting NFkappaB activation by small molecules as a therapeutic strategy. Biochim. Biophys. Acta 2010, 1799, 775-787. [CrossRef] [PubMed]

105. Hayden, M.S.; Ghosh, S. NF-kB, the first quarter-century: Remarkable progress and outstanding questions. Genes Dev. 2012, 26, 203-234. [CrossRef] [PubMed]

106. Kang, J.S.; Yoon, Y.D.; Han, M.H.; Han, S.B.; Lee, K.; Kang, M.R.; Moon, E.Y.; Jeon, Y.J.; Park, S.K.; Kim, H.M. Estrogen receptor-independent inhibition of tumor necrosis factor-alpha gene expression by phytoestrogen equol is mediated by blocking nuclear factor-kappa B activation in mouse macrophages. Biochem. Pharm. 2005, 71, 136-143. [CrossRef] [PubMed]

107. Kang, J.S.; Yoon, Y.D.; Han, M.H.; Han, S.D.; Lee, K.; Park, S.K.; Kim, H.M. Equol inhibits nitric oxide production and inducible nitric oxide synthase gene expression through down-regulating the activation of Akt. Int. Immunopharmacol. 2007, 7, 491-499. [CrossRef] [PubMed]

108. Lephart, E.D. A review of the role of estrogen in dermal aging and facial attractiveness in women. J. Cosmet. Dermatol. 2018, in press.

(C) 2018 by the author. Licensee MDPI, Basel, Switzerland. This article is an open access article distributed under the terms and conditions of the Creative Commons Attribution (CC BY) license (http://creativecommons.org/licenses/by/4.0/). 